\title{
Comparative Study of 10 X-STR Markers in Populations of Northeast Argentina
}

G. Paula Di Santo Meztler,1* Laura A. Glesmann,1 M. Esther Esteban,2 Santiago del Palacio,3 Marta G. Méndez,4 and Cecilia I. Catanesi 1,5

1Laboratorio de Diversidad Genética, IMBICE (CICPBA-UNLP-Consejo Nacional de Investigaciones Científicas y Técnicas, La Plata, Argentina.

2Section of Zoology and Biological Anthropology, Department of Evolutionary Biology, Ecology and Environmental Sciences, University of Barcelona, Barcelona, Spain. Institut de Recerca de la Biodiversitat, Universitat de Barcelona, Barcelona, Spain. 3Instituto Argentino de Radioastronomía, CCT-La Plata, Consejo Nacional de Investigaciones Científicas y Técnicas, CICPBA, Villa Elisa, Argentina. 4Departamento de Antropología, Facultad de Ciencias Naturales y Museo, UNLP, La Plata, Argentina.

5Cátedra de Genética, Facultad de Cs. Naturales y Museo, UNLP, La Plata, Argentina.

*Correspondence to: G. Paula Di Santo Mezlter, Laboratorio de Diversidad Genética, IMBICE (CICPBA-UNLP-Consejo Nacional de Investigaciones Científicas y Técnicas, La Plata, Argentina. E-mail: unlpbiotec@gmail.com.

Notes on contributors: G.P.D.S.M. and C.I.C.: study design; G.P.D.S.M. and L.A.G.: data processing; S.D.P., G.P.D.S.M., C.I.C., and M.E.E.: data analysis; S.D.P., G.P.D.S.M., and C.I.C.: manuscript preparation.

Short Title: Study of 10 X-STR in Populations of Northeast Argentina KEY WORDS: X CHROMOSOME, MESOPOTAMIA, GRAN CHACO, STR, GENETIC 


\title{
VATIATION, NATIVE POPULATIONS, ARGENTINA, ADMIXED POPULATIONS.
}

\begin{abstract}
In northeast Argentina, different Amerindian communities share territory and history with settlers, mainly Europeans. Due to miscegenation, the current Argentinian population has a particular structure that can be de- scribed through the $\mathrm{X}$ chromosome variation. Our objectives are: to describe the variation of $10 \mathrm{X}$-STRs in urban populations of the Argentinian regions known as Gran Chaco and Mesopotamia; to report the forensic parameters of these STRs, and to estimate the European and indigenous genetic components in these regions. Population and forensic parameters were estimated for 419 individuals from the analysed populations, including two indigenous groups, Wichí and Mocoví, previously reported. Population structure was estimated through $F_{\text {st }}$ and $R_{\text {st }}$ distances and AMOVA calculations. The indigenous American and European components were assessed with STRUCTURE. XSTRs showed a high level of genetic variability in urban and indigenous populations. Indigenous people of the Gran Chaco region showed significant differentiation from the urban samples $\left(F_{\text {st }} 5.5 \%\right)$ and also among themselves $\left(F_{\text {st }} 5.3 \%\right)$. The genetic differentiation among urban groups is almost negligible instead population from Misión Nueva Pompeya differed from the rest of the city populations. Forensic parameters indicate that these X-STRs are useful as a complement to paternity tests. The set of 10 STRs could be a good tool for population differences.
\end{abstract}




\section{Argentinian Population History and Present Composition}

The current population of Argentina is the result of several generations of intermixing among various groups at different times, including indigenous communities, Spanish conquerors (early 1500s) and Africans (arriving as slaves since the late 1500s), and a large European immigrant population (arriving between 1870 and 1950) (Avena et al. 2006). The European component in Argentina was introduced by two major events: the Spanish colonisation which was violent, and the successive migratory waves of Europeans who fled because of wars and famine (Martínez Sarasola 2005; Gallero et al. 2009). The miscegenation was strong; it has been reported that a considerable proportion of the Argentine population has at least one Indigenous American ancestor (Corach et al. 2010).

This work focuses on the study of two regions of Argentina: Argentinian Gran Chaco, which includes the provinces of Chaco, Formosa and (partly) Santa Fe, Salta and Santiago del Estero, and the Argentinian Mesopotamia, which includes the provinces of Misiones, Corrientes and Entre Ríos. In particular, these two regions (Argentinian Mesopotamia and Gran Chaco) have well- distinguished phytogeographic characteristics and different indigenous populations. (Martínez Sarasola 2005; Heguy 2012).

The Gran Chaco region consists of an extensive wooded plain inhabited by indigenous people of the Mataco-Mataguayo, Guaycurú, Lule-Vilela, Arawak, and Tupi-Guaraní linguistic groups (Martínez Sarasola 2005), which accord- ing to (Crossetti et al. 2008), arrived to the region about 5,000 years ago. The region within Argentinian Gran Chaco that was referred to as the "Impenetrable Chaqueño" by early European settlers, is inhabited mainly by the Wichí people, who encountered Franciscan missionaries in 1900, upon the founding of the Nueva Pompeya Mission (Franceschi and Dasso 2010). 
The first Europeans arrived to the province of Chaco in 1528 and tried to occupy the land inhabited by indigenous communities. In 1872 a group of people from the province of Corrientes and Italian immigrants settled in this region (Tissera 2008; De Pompert de Valenzuela 2008). Some years later the city of Resistencia was founded (1875), and in 1884 it was consecrated as capital of the province of Chaco, as it is at present (Tissera 2008; De Pompert de Valenzuela 2008). Between 1895 and 1914, people from Paraguay and from the neighbouring province of Corrientes arrived to the city (Franceschi and Dasso 2010; Solá 2009). At the beginning of the 20th century, the population of the Chaco was a small, heterogeneous and unequally distributed in the province (Maeder 2012).

In the case of the Mesopotamian region according to (Heguy 2012), the Guarani people arrived from the Amazonian region, at least 1,000 years ago, following the natural course of the Paraná and Paraguay rivers (Sala et al. 2010; Tarragó 2000). In 1604 the Jesuits arrived to the current province of Misiones during the Spanish invasion of the area and established numerous missions, but in 1767 the Jesuits were expelled from America, and indigenous emigrated to Corrientes and Santa Fe provinces for work, while others rejoined their native communities (Heguy 2012). After the initial Spanish settlers, Misiones received a later wave of immigration in the northern part of the province, mainly of German migrants. That colonization gave rise to settler cities like Eldorado, Puerto Rico and Montecarlo (Junta de Estudios Históricos del Municipio de Eldorado 2015).

Finally, the capital city of Corrientes, also named Corrientes, was founded by Spaniards and their descendants born in America. The initial settlers of the city of Corrientes gradually joined the local Amerindian population (Vara 1985). In contrast with the situation in Misiones, there were only a few religious missions in the province 
(Heguy 2012; Pérez 1936).

\section{Chromosome}

The patterns of allele distribution of different markers in the $\mathrm{X}$ chromosome can be very informative in comparative studies because of the special features of the $\mathrm{X}$ chromosome which make it a potential source to uncover ethnic differences (Bourgeois et al. 2009; Szibor 2007).

From the perspective of population genetics, the variation of the human $\mathrm{X}$ chromosome is a valuable complement to the genetic variation of autosomes. Given its mode of inheritance, the $\mathrm{X}$ chromosome presents a lower rate of mutation, showing different genetic diversity than autosomes and offering particular opportunities to selection action. It is also more exposed to the effects of genetic drift and, therefore, it is likely to show more pronounced population structures (Hamosh et al. 2000; Shaffner 2004; Szibor 2007).

Short tandem repeats (STRs) are very polymorphic markers widely used in forensic and population genetics. Their high mutation rates and multiallelic spectra make STRs particularly useful for population studies. In forensic genetics, X-STRs can complement the analysis of Y and autosomal STRs, especially in paternity cases where the offspring is female, or in some complex kinship testing cases (Santamaría et al. 2018)

Information on uniparental variability for populations in the north of Argentina showed a high component of Amerindian mitochondrial DNA, and a very low proportion of indigenous Y chromosome (Bobillo et al. 2009; Rodríguez Golpe et al. 2017a,b; Salas et al. 2008). These results supported the historical events that the first encounters between indigenous women and Spanish men gave rise to an important mestizo society. 
Given the pattern of inheritance of $\mathrm{X}$-chromosome variation, females can influence the $\mathrm{X}$ variation of current populations double than males, thus we can interpret that an important indigenous component may be present in $\mathrm{X}$-chromosome variation, more than in autosomal chromosomes. Each region of Argentina has a particular history and a different contribution of European and indigenous genetic components. Even the Amerindian groups that inhabited the territory were different: the Wichí and Mocoví people, among others, predominated in Gran Chaco, while the Guaraní people predominated in Mesopotamia. Moreover, in a previous study, genetic differences have been found among some of these indigenous communities (Catanesi et al. 2007).

The aim of this study is (i) to describe the variation of 10 polymorphisms of the $\mathrm{X}$ chromosome STR in 6 urban populations of Gran Chaco and Mesopotamia, (ii) to report the forensic parameters of these STR to increase the forensic databases, and (iii) to estimate the European and indigenous genetic components in these regions. In addition, we will compare our data with information from other indigenous and urban Argentine populations to evaluate the usefulness of $X$ chromosome STRs to differentiate among indigenous communities, and to understand the genetic background of the different urban populations, in the light of their different admixed origins.

\section{Methods}

\section{Populations}

We analysed a total of 419 samples from healthy, unrelated persons of both sexes, and from five different locations at three provinces in northeast Argentina: the capital city of Chaco (Resistencia; $n=141,78$ females, 63 males), a small city of Chaco (Misión Nueva Pompeya; $n=54,23$ females, 31 males), the capital city of Corrientes (Corrientes, $n=92 ; 32$ females, 60 males), the capital city of Misiones 
(Posadas; $n=52,28$ females, 24 males) and another important city of Misiones (Eldorado, $n=54$ ). Concerning Eldorado, samples were separated into two groups according to the grandparents reported origin. We labeled them as Eldorado A ( $n=$ 27; 13 females, 14 males) when donors knew that their four grandparents were German and/or Swiss, and we labeled donors who did not know the origin of all four grandparents as Eldorado B ( $n=27 ; 11$ females, 16 males) (Di Santo Meztler et al. 2018). Adult donors were recruited in health facilities and or private health centers, and asked to participate in this project while waiting for a medical appointment. The health institutions were as follows: Samples from Posadas: different public hospitals of the city, Resistencia: Hospital Central de Odontología and two private centers, Sanatorio Frangioli and Sanatorio Güemes; Misión Nueva Pompeya: Hospital Regional Misión Nueva Pompeya. Samples from Eldorado were collected in a private laboratory of clinical analysis, and those from Corrientes were collected during a campaign by physician Darío Martín González. The project was approved by the Ethics Committee at IMBICE. DNA was isolated from buccal cells and peripheral blood samples as in Gemmell and Akiyama (1996). Seven populations were used for comparisons: populations from Entre Ríos, Córdoba, Buenos Aires and Río Negro (Argentina) and Galicia (Spain) reported by Gusmão et al. (2009); and Mocoví and Wichí populations from Glesmann et al. (2013). The lack of references for African populations in public databases for the STR markers included in this work, prevented us from making comparisons or calculating a possible African contribution.

\section{Genetic Determinations}

Samples were genotyped for 10 noncoding X-STR markers (DXS8378, DXS9902, 
DXS7132, DXS9898, DXS6809, DXS7133, DXS6789, GATA172D05, GATA31E08, and

DXS7423) in a single multiplex reaction, according to Gusmão et al. (2008, 2009).

Polymerase chain reaction fragments were separated and detected through capillary electrophoresis in an ABI PRISM 3130 genetic analyser (Applied Biosystems, Inc.).

\section{Statistical Analysis}

Allele frequencies were calculated employing the software RStudio v.0.99.893 (Team 2008). Heterozygosity and Hardy-Weinberg equilibrium (HWE) were calculated only for female subsamples. Genetic distances were approached through AMOVA, $F_{\text {st }}$ and $R_{\mathrm{st}}$ distances using both female and male data, through the program ARLEQUIN v.3.5 (Excoffier and Lischer 2010). Program Past was used to make MDS graphics (Hammer et al. 2001). To infer the population structure, the program STRUCTURE v.2.1 (Hubisz et al. 2009) was used assuming a model of $k$ population groups, with $k$ between 1 and 5; all runs were performed using a burn-in period of $10^{5}$ iterations followed by $10^{5}$ iterations, and a repetition number of 10 . To choose the best $k$ in each case, Structure Harvester software was used (Earl and von Holdt 2012). Bonferroni correction was applied in all analyses except for AMOVA.

The adaptation of the tables for R program, Structure, and Arlequin was made using GA-TA program (http://gata.fcaglp.unlp.edu.ar/).

Another feature to consider is the forensic efficiency of using the DNA markers in casework involving relationship testing. Such estimates describe the theoretical value of using the specific markers for different forensic genetic situations and differ from case specific values. The estimation of such parameters is most often based on the number of distinctive alleles found in the population and their corresponding frequencies. The power of discrimination $P D$ is defined as the probability of discriminating between two 
unrelated individuals. Polymorphism Informative Content $P I C$ can be interpreted as the probability that the maternal and paternal alleles of a child are deducible, or the probability of being able to deduce which allele a parent has transmitted to the child (Bolstein et al. 1980; Guo and Elston 1999). The power of exclusion, $P E$, is defined as the fraction of individuals having a DNA profile that is different from that of a randomly selected individual in a typical paternity case. The value for each individual case will vary (Brenner and Morris 1990). These parameters were performed using an online software ChrX-STR.org 2.0 Calculator (http://www.chrx-str.org/) (Szibor et al. 2006).

\section{Results}

\section{Allele Frequencies, Hardy-Weinberg Equilibrium, and Heterozygosity}

The frequencies and the observed and expected heterozygosity of the $10 \mathrm{STR}$ alleles for the six populations are shown in Table 1. The alleles DXS9902*15, DXS7132*10, GATA1705*14 and DXS6809*37 were only present in the Resistencia population. DXS9898*17 was only observed in Misión Nueva Pompeya (MNP), whereas DXS6789*13 was only found in Corrientes and DXS7423*12 in Eldorado. There were no significant differences in allele frequencies between females and males. The highest values for the number of alleles $\left(n_{\mathrm{x}}\right)$ were found in the capital cities and in Mision Nueva Pompeya, while the lowest was observed in Eldorado A (Table A.1).

Frequency distributions fitted the HWE with the exceptions of GATA31E08 for Corrientes ( $p=0.03)$, DXS7133 for Eldorado A $(p=0.02)$, GATA172D05 for Eldorado B $(p=0.03)$ and Resistencia $(p=0.04)$, and DXS7132 for Mis- ión Nueva Pompeya $(p=0.04)$. These values were not significant after the Bonferroni correction $(p=0.005)$.

STRs showed high heterozygosity in all cases. The highest average 
heterozygosity was found in Eldorado B (0.75), followed in decreasing order by Posadas, Chaco, Resistencia, Corrientes and Eldorado A as shown in Table 1. The forensic parameters $P I C, P E, P D f$, and $P D m$ are reported in Table A.2 for Corrientes, Posadas, Eldorado A, Eldorado B, Resistencia, Misión Nueva Pompeya, Wichí, and Mocoví. In the case of Corrientes and Mocoví, the high-est values for these parameters were found for DXS7132 while for Posadas, Eldorado A and Eldorado B, the highest values were found for GATA172D05.

Finally, for Resistencia, Misión Nueva Pompeya and Wichí, the highest values were found for DXS6809.

\section{Population Structure and Comparisons among Urban and Indigenous Populations}

$R_{\mathrm{st}}$ and $F_{\text {st }}$ distances are indicated in Table A.3. For both distances, the highest values are observed between indigenous and urban groups, and the lowest, and nonstatistically different from zero, among urban samples with the exception of Mision Nueva Pompeya, which differed from most of the urban populations. Distance values between the two indigenous populations are high and similar to the values shown between them and the urban samples. A multidimensional scaling plot (MDS) using $R_{\mathrm{st}}$ distances is shown in Figure 2. The first dimension of the graph separates indigenous people of Gran Chaco from the rest of the populations, suggesting an Amerindian component to the left and a European component to the right of the plot. The second dimension separates the two indigenous populations, with the Wichí people located on the top and the Mocoví at the bottom. Misión Nueva Pompeya is a particular case because it is clustered in an intermediate position between indigenous and urban populations.

AMOVA calculations allowed an estimation of the amount of population 
variability behind the clusters observed in the MDS plot. High values of AMOVA $\left(F_{\mathrm{st}}\right.$ of $5.2 \%, p$-value $<0.001$ ) were observed among the two indigenous groups and the urban samples from Gran Chaco (Resistencia and MNP regions). A similar value was observed in the comparison between Wichí vs Mocoví (global $F_{\text {st }}$ value of 5.5\% ( $p$-value $<$ $0.001)$ ). When only urban populations were considered, the global $F_{\text {st }}$ was extremely low, either when Gran Chaco and Mesopotamia were compared $\left(F_{\text {st }} 0.5 \%\right.$-value $\left.<0.001\right)$ or when all Argentinian samples were included $(0.3 \% p$-value $<0.01)$. Variability among populations from the cities was almost negligible $\left(F_{\text {st }} 0.5 \%\right.$ for Gran Chaco and Mesopotamia regions altogether; $0.3 \%$ for all Argentinean urban cities).

We used STRUCTURE software to infer the Amerindian and European proportion in urban populations of Argentina, employing the data of two indigenous communities of Wichí and Mocoví, and the European population of Galicia (Spain) as references. Table 2 indicates the proportion of membership of each predefined population in each of the two clusters. We associated an indigenous component to cluster 1, and an European component to cluster 2. As expected, all urban samples had a large proportion of cluster 2 . In contrast, all indigenous populations had a large proportion of cluster 1. MNP showed more Amerindian component (39\%) than the remaining urban populations of northeast Argentina (16.4\%-33.6\%). The information of Table 2 is graphically represented in Figure 3. As it can be seen from the comparison of the individual bars, the internal heterogeneity within each population is high.

Regarding forensic parameters, the set of 10 STRs resulted informative in both urban and indigenous populations. In an analysis of each marker separately, the forensic parameters are notably more informative in the urban samples, but when considered altogether their power of discrimination is not only high in urban populations (as expected) but also in indigenous communities of Wichí and Mocoví. 


\section{Discussion}

In this work, we describe the variation of $10 \mathrm{X}$-chromosome STRs in 6 urban populations from the Argentinian regions of Gran Chaco (Resistencia and Misión Nueva Pompeya) and Mesopotamia (Corrientes, Posadas, and Eldorado (A and B) populations). Population parameters are consistent with the expected outcome for urban populations with high gene flow. The capital cities of the northeastern provinces considered in this work have been initially settled by people from several origins, and afterwards they have received immigration from other regions of Argentina and also from bordering countries, giving an identity which is particular to each city.

Our results are in accordance with previous reports on $\mathrm{X}$ chromosome variation in other populations (Gomes et al. 2009; Gusmão et al. 2009; Zambrano et al. 2015). Although no evidence of population stratification along Argentina has been recently reported for a different set of X-STR markers, no indigenous populations were included in such study (García et al. 2019).

We observed a high level of genetic diversity in all populations including indigenous communities, as expected for multiallelic markers selected for forensic purposes. Demarchi and García Ministro (2008) already observed a high level of genetic diversity in indigenous people from Chaco analyzing both mitochondrial and Y chromosome markers, a fact that is noticeable in communities with relatively low population sizes.

Although our sample size might not exactly represent some of the populations here considered, these data allowed to differentiate urban populations from indigenous groups (MDS plot and bar plots: Figures 2 and 3). Interestingly, genetic 
distances and admixture values joined Eldorado B, Río Negro and Misión Nueva Pompeya in a group with more than $30 \%$ of Amerindian component, while Eldorado A exhibited a much lower Amerindian component. It is also important to remark that we already reported a sub-structure in the X chromosome variability of the population of Eldorado city, likely originated by European migratory flow at the beginning of the 20th century (Di Santo Meztler et al. 2018). These results illustrate how colonization took place in Eldorado city, given that immigrants were distributed by the owner of the lands (Mr. Adolfo Schwelm) in separate land plots according to their different nationalities (Junta de Estudios Históricos del Municipio de Eldorado 2015).

Our results are consistent with the fact that current Argentinean popu- lations were originated in an admixture of inhabitants descending from in- digenous and Spanish settlers with later contributions from other European countries, mostly Italians. A particular case is the population of Misión Nueva Pompeya: this population does not cluster with those from other Argentinean cities in the MDS plot and shows the highest indigenous admixture value (0.390) among them. According to their geographic position in the Chaco province, where the Wichí indigenous people are distributed, one would ex- pect the contribution of Wichí population. However, in the MDS plot, Misión Nueva Pompeya does not show any particular relationship with the Wichí, but resulted in an intermediate position. Cultural differences can be the main factor of separation between urban people living in MNP and indigenous communities living in the proximities of the city. Wichí people tend to marry persons living within their communities, with whom they share language and uses. Another possible factor for the lack of any particular closeness between MNP and Wichí could be the fact that this city started as a mission which was founded and abandoned several times. In 
each episode, the indigenous people who inhabited the mission returned to the forest (Colazo 2003) and, at each re-foundation, a new group of indigenous people contributed to the city, making it difficult for them to integrate to urban habits. This process, together with the presence of admixed people who came to the city for administrative work, contributed to the particular genetic background of Misión Nueva Pompeya. Concerning the Mocoví community, their position in the plot shows that they are currently less isolated, and maintain certain contact with urban people, gradually joining the urban population looking for education and job, as previously reported (Franceschi and Dasso 2010).

The STRs here analysed, which have been initially selected for forensic purposes (Gusmão et al. 2009), and widely used for resolution of paternity cases, showed an overall high intrapopulation genetic diversity. Moreover, they also showed interpopulation diversity, as they proved to be useful for discriminating not only urban from indigenous populations, but also between indigenous populations. In this way, our results allowed to set down a relationship be- tween the historical events and the genetic information contained in the $\mathrm{X}$ chromosome. Another set of markers is gaining place among human identification laboratories within the country, the STR Investigator R Argus X-12, including 12 STRs conforming 4 linkage groups, and some information on the variation of these markers in Argentina is currently available (García et al. 2019). However, the STRs included in the present work have been widely applied in both population and forensic studies in Argentina, with good results. Therefore, further analyses in both sets of markers would be desirable to characterize in deep these and other populations from Argentina and even from South America. 


\section{Conclusions}

In summary, this set of $10 \mathrm{X}-\mathrm{STR}$ is informative for forensic purposes in both urban and indigenous populations, being useful as a complement to paternity tests of female kinship. These X chromosome markers showed a significant differentiation among indigenous and urban populations, allowing to set an estimation of the amount of the Amerindian component present in the urban communities. Further studies using these X-STRs would be very useful for the characterization of other Argentinean populations and the understanding of particular historical facts that have taken place in each region.

\section{Acknowledgments}

We thank Raúl Brindi, Pablo Martina, Daniela Arntzen, Martín González, Isaías Armoa, and Carina Argüelles for collecting samples from donors. We thank Marisa Roman (St. Joseph's University, Philadelphia, PA USA) and Alejandro Roman (University of Pennsylvania, Philadelphia, PA USA) for revising the manuscript. M.E.E. acknowledges support from 2017 SGR 1630 Grup de Recerca en Antropologia Biològica (GREAB). This work was supported by grants from CONICET, Argentina (PIP 2015-2017 11220150100930, and PUE 2017$202222920170100105 C O)$, and from UNLP, Argentina (PID 2019-2020 N895).

Received 20 May 2019; accepted for publication 28 August 2019. 


\section{Literature Cited}

Avena, S. A., A. S. Goicoechea, J. M. Dugoujon et al. 2006. Mezcla génica en la Region Metropolitana de Buenos Aires. Medicina (B. Aires) 66:113-118.

Bobillo, M. C., B. Zimmermann, A. Sala et al. 2010. Amerindian mitochondrial DNA haplogroups predominate in the population of Argentina: Towards a first nationwide forensic mitochondrial DNA sequence database. Int. J. Legal Med. 124:263-268.

Botstein, D., R. L. White, M. Skolnick et al. 1980. Construction of a genetic linkage map in man using restriction fragment length polymorphisms. Am. J. Hum. Genet. $32: 314-331$.

Bourgeois, S., V. Yotova, S. Wang et al. 2009. X-chromosome lineages and the settlement of the Americas. Am. J. Phys. Anthropol. 140:417-428.

Brenner, C. H., and J. W. Morris. 1990. Paternity index calculations in single locus hypervariable DNA probes: Validation and other studies. In Proc. Int. Symp. Hum. Identif. 1989. Madison, WI: Promega Corporation, 21-52.

Catanesi, C. I., P. F. Martina, G. Giovambattista et al. 2007. Geographic structure in Gran Chaco Amerindians based five X-chromosome STRs. Hum. Biol. 79:463-474.

Colazo, S., 2003. Relatos orales, historia y temporalidad. Comunicaciones Cientificas y Tecnológicas. Corrientes, Argentina: Universidad Nacional del Nordeste.

Corach, D., O. Lao, C. Bobillo et al. 2010. Inferring continental ancestry of Argentineans from autosomal, Y-chromosomal and mitochondrial DNA. Ann. Hum. Genet. 74:6576.

Crossetti, S. G., D. A. Demarchi, P. E. Raimann et al. 2008. Autosomal STR genetic variability in the Gran Chaco native population: Homogeneity or heterogeneity? Am. J. Hum. Biol. 20:704-711.

Demarchi, D. A., and A. García Ministro. 2008. Genetic structure of native populations from 
the Gran Chaco region, South America. Int. J. Hum. Genet. 8:131-141.

de la Mercedes Tissera, R. 2008. Chaco: Historia General. Resistencia, Chaco, Argentina: Librería de la Paz.

de Pompert de Valenzuela, M. C. 2008. El Poblamiento del Chaco: Génesis y Primitivo Desarrollo. Corrientes, Argentina: Moglia SRL.

Di Santo Meztler, G. P., S. del Palacio, M. E. Esteban et al. 2018. Genetic differentiation of north-east Argentina populations based on 30 binary X chromosome markers. Front. Genet. 9:208.

Earl, D. A., and B. M. vonHoldt. 2012. STRUCTURE HARVESTER: A website and program for visualizing STRUCTURE output and implementing the Evanno method. Conserv. Genet. Resour. 4:359-361.

Excoffier, L., and H. E. Lischer. 2010. Arlequin suite ver 3.5: A new series of programs to perform population genetics analyses under Linux and Windows. Mol. Ecol. Resour. 10:564-567.

Franceschi, Z. A., and M. C. Dasso. 2010. Etno-Grafias: La Escritura como Testimonio entre los Wichi. Buenos Aires, Argentina: Corregidor.

Gallero, M. C., and E. M. Krautstofl. 2009. Proceso de poblamiento y migraciones en la Provincia de Misiones, Argentina (1881-1970). Avá 16:245-264.

García, M. G., C. I. Catanesi, G. A. Penacino et al. 2019. X-chromosome data for 12 STRs: Towards an Argentinian database of forensic haplotype frequencies. Forensic Sci. Int. Genet. 41:e8-e13.

Gemmell, N. J., and S. Akiyama. 1996. An efficient method for the extraction of DNA from vertebrate tissues. Trends Genet. 12:338-339.

Glesmann, L. A., P. F. Martina, and C. I. Catanesi. 2013. Genetic variation of X-STRs in the Wichí population from Chaco Province, Argentina. Hum. Biol. 85:687-698. 
Golpe, R., D. Carmen, M. E. Schwab et al. 2017a. Linajes maternos en las ciudades de Formosa y Corrientes, Argentina. In Libro de Resúmenes de las Decimoterceras Jornadas Nacionales de Antropologia Biológica: Horizontes en Antropologia Biológica, R. A. Guichón, P. García Laborde, L. O. Valenzuela, J. M. B. Motti, and M. Martucci, eds. La Plata, Buenos Aires, Argentina: Asociación de Antropología Biológica, 114.

Golpe, R., D. Carmen, M. E. Schwab et al. 2017b. Aportes de los linajes paternos nativos y alóctonos a las poblaciones contemporáneas de Formosa y Corrientes, Argentina. In Libro de Resúmenes de las Decimoterceras Jornadas Nacionales de Antropologia Biológica: Horizontes en Antropologia Biológica, R. A. Guichón, P. García Laborde, L. O. Valenzuela, J. M. B. Motti, and M. Martucci, eds. La Plata, Buenos Aires, Argentina: Asociación de Antropología Biológica, 163.

Gomes, I., V. Pereira, V. Gomes et al. 2009. The Karimojong from Uganda: Genetic characterization using an X-STR decaplex system. Forensic Sci. Int. Genet. 3:e127-e128.

Guo, X., and R. C. Elston. 1999. Linkage information content of polymorphic genetic markers. Hum. Hered. 49:112-118.

Gusmão, L., C. Alves, P. Sánchez-Diz et al. 2008. Results of the GEP-ISFG collaborative study on an X-STR decaplex. Forensic Sci. Int. Genet. Suppl. Ser. $1: 677-679$

Gusmão, L., P. Sánchez-Diz, C. Alves et al. 2009. A GEP-ISFG collaborative study on the optimization of an X-STR decaplex: Data on 15 Iberian and Latin American populations. Int. J. Legal Med. 123:227-234.

Hammer, Ø., D. A. T. Harper, and P. D. Ryan. 2001. PAST: Paleontological statistics software package for education and data analysis. Palaeontologia Electronica 
4:1-9. https://palaeo-electronica.org/2001_1/past/past.pdf.

Hamosh, A., A. F. Scott, J. Amberger et al. 2000. Online Mendelian Inheritance in Man (OMIM). Hum. Mutat. 15:57-61.

Heguy, S. 2012. Misiones: Jesuitas y Guaranies: Una experiencia única. Buenos Aires, Argentina: Golden Company.

Hubisz, M. J., D. Falush, M. Stephens et al. 2009. Inferring weak population structure with the assistance of sample group information. Mol. Ecol. Resour. $9: 1,322-1,332$.

Junta de Estudios Históricos del Municipio de Eldorado. 2015. Historias de Eldorado Volumen 2. Eldorado, Misiones.

Maeder, E. J. A. 2012. Historia del Chaco. Chaco, Argentina: ConTexto.

Martínez Sarasola, C. 2005. Nuestros Paisanos los Indios. Vida, historia y destino de las comunidades indigenas en la Argentina. Buenos Aires, Argentina: Emecé.

Pérez Colmán, C. B. 1936. Historia de Entre Ríos: Época Colonial, 1520-1810. Paraná, Argentina: Imprenta de la Provincia.

R Core Team. 2008. R: A Language and Environment for Statistical Computing. Vienna: R Foundation for Statistical Computing. https://www.R-project.org.

Sala, A., C. F. Argüelles, M. E. Marino et al. 2010 Genetic analysis of six communities of Mbyá-Guaraní inhabiting northeastern Argentina by means of nuclear and mitochondrial polymorphic markers. Hum. Biol. 82:433-456.

Salas, A., J. C. Jaime, V. Álvarez-Iglesias et al. 2008. Gender bias in the multiethnic genetic composition of central Argentina. J. Hum. Genet. 53:662-674.

Santamaría, J., M. M. Álvarez-Álvarez, M. E. Esteban et al. 2018. Dinucleotide (CA)n tandem repeats on the human $\mathrm{X}$-chromosome and the history of the Mediterranean populations. Ann. Hum. Biol. 45:72-76. 
Schaffner, S. F. 2004. The X chromosome in population genetics. Nat. Rev. Genet. 5:4351.

Solá, M. D. 2009. Región Chaqueña: Wichís. In Aborigenes Argentinos. Buenos Aires, Argentina: Editorial Gradifco, 27-60.

Szibor, R. 2007. X-chromosomal markers: Past, present and future. Forensic Sci. Int. Genet. 1:93-99.

Szibor, R., S. Hering, and J. Edelmann. 2006. A new web site compiling forensic chromosome X research is now online. Int. J. Legal Med. 120:252-254.

Tarragó, M. N., ed. 2000. Nueva Historia Argentina: Los Pueblos Originarios y la Conquista. Buenos Aires, Argentina: Editorial Sudamericana.

Vara, A. 1985. Todo es Historia: Corrientes en el Mundo Guaranitico. Buenos Aires, Argentina: Talleres Gráficos de Alemann SRL.

Zambrano, A. K., G. Morejón, J. Galarza et al. 2015. Genetic data of an X-STR decaplex in Ecuadorian population (P). Forensic Sci. Int. Genet. Suppl. Ser. 5:e91-e92. 
Table 1. Allele Frequencies of 10 X-STR for Corrientes, Posadas, Eldorado A, Eldorado B, Resistencia and Misión Nueva Pompeya

\begin{tabular}{|c|c|c|c|c|c|c|c|}
\hline \multirow[b]{2}{*}{ Marker } & \multirow[b]{2}{*}{ Alelle } & Corrientes & \multicolumn{3}{|c|}{ Misiones } & \multicolumn{2}{|c|}{ Chaco } \\
\hline & & Corrientes & Pos & EldA & EldB & $\begin{array}{c}\text { Res } \\
\text { MNP }\end{array}$ & MNP \\
\hline \multirow{6}{*}{ DXS8378 } & 9 & 0 & 0.03 & 0 & 0.03 & 0 & 0 \\
\hline & 10 & 0.39 & 0.45 & 0.25 & 0.39 & 0.45 & 0.39 \\
\hline & 11 & 0.26 & 0.29 & 0.34 & 0.47 & 0.33 & 0.35 \\
\hline & 12 & 0.3 & 0.21 & 0.38 & 0.11 & 0.21 & 0.23 \\
\hline & 13 & 0.05 & 0.03 & 0.03 & 0 & 0.02 & 0.03 \\
\hline & 14 & 0 & 0 & 0 & 0 & 0 & 0 \\
\hline \multirow[t]{2}{*}{ Heterozygosity } & Obs & 0.67 & 0.67 & 0.73 & 0.55 & 0.57 & 0.52 \\
\hline & Exp & 0.7 & 0.69 & 0.72 & 0.63 & 0.66 & 0.68 \\
\hline \multirow{7}{*}{ DXS9902 } & 9 & 0 & 0 & 0 & 0.03 & 0.01 & 0 \\
\hline & 10 & 0.02 & 0.05 & 0.08 & 0.03 & 0.02 & 0.06 \\
\hline & 11 & 0.43 & 0.35 & 0.25 & 0.44 & 0.36 & 0.33 \\
\hline & 12 & 0.29 & 0.38 & 0.31 & 0.18 & 0.39 & 0.33 \\
\hline & 13 & 0.25 & 0.21 & 0.33 & 0.32 & 0.2 & 0.25 \\
\hline & 14 & 0.01 & 0.01 & 0.03 & 0 & 0.02 & 0.03 \\
\hline & 15 & 0 & 0 & 0 & 0 & 0.01 & 0 \\
\hline \multirow[t]{5}{*}{ Heterozygosity } & Obs & 0.64 & 0.67 & 0.55 & 0.7 & 0.71 & 0.87 \\
\hline & Exp & 0.68 & 0.71 & 0.76 & 0.69 & 0.67 & 0.72 \\
\hline & 10 & 0 & 0 & 0 & 0 & 0.01 & 0 \\
\hline & 11 & 0.02 & 0 & 0.11 & 0 & 0 & 0.03 \\
\hline & 12 & 0.08 & 0.08 & 0.04 & 0.05 & 0.11 & 0.06 \\
\hline
\end{tabular}

\begin{tabular}{|c|c|c|c|c|c|c|c|}
\hline \multirow[b]{2}{*}{ Marker } & \multirow[b]{2}{*}{ Alelle } & \multirow{2}{*}{$\frac{\text { Corrientes }}{\text { Cor }}$} & \multicolumn{3}{|c|}{ Misiones } & \multicolumn{2}{|c|}{ Chaco } \\
\hline & & & Pos & EldA & EldB & Res & MNP \\
\hline \multirow{6}{*}{ DXS6789 } & 11 & 0 & 0 & 0 & 0 & 0 & 0 \\
\hline & 13 & 0.01 & 0 & 0 & 0 & 0 & 0 \\
\hline & 15 & 0.05 & 0.06 & 0 & 0.05 & 0.04 & 0.01 \\
\hline & 16 & 0.08 & 0.03 & 0.06 & 0.05 & 0.05 & 0.06 \\
\hline & 17 & 0.02 & 0.01 & 0 & 0 & 0.01 & 0.01 \\
\hline & 18 & 0 & 0.01 & 0 & 0.03 & 0 & 0 \\
\hline \multirow{8}{*}{ Heterozygosity } & 19 & 0.02 & 0.01 & 0 & 0 & 0.03 & 0.01 \\
\hline & 20 & 0.48 & 0.44 & 0.56 & 0.34 & 0.46 & 0.46 \\
\hline & 21 & 0.2 & 0.26 & 0.11 & 0.32 & 0.21 & 0.32 \\
\hline & 22 & 0.11 & 0.14 & 0.17 & 0.11 & 0.14 & 0.09 \\
\hline & 23 & 0.02 & 0.04 & 0.11 & 0.11 & 0.05 & 0.03 \\
\hline & 24 & 0.02 & 0 & 0 & 0 & 0.01 & 0 \\
\hline & Obs & 0.55 & 0.78 & 0.67 & 0.91 & 0.61 & 0.74 \\
\hline & Exp & 0.66 & 0.76 & 0.67 & 0.77 & 0.74 & 0.72 \\
\hline \multirow{6}{*}{ DXS7133 } & 7 & 0.02 & 0 & 0 & 0 & 0.01 & 0.01 \\
\hline & 8 & 0.01 & 0.01 & 0 & 0 & 0.01 & 0 \\
\hline & 9 & 0.48 & 0.49 & 0.57 & 0.58 & 0.54 & 0.53 \\
\hline & 10 & 0.17 & 0.19 & 0.03 & 0.05 & 0.18 & 0.15 \\
\hline & 11 & 0.26 & 0.26 & 0.37 & 0.32 & 0.24 & 0.24 \\
\hline & 12 & 0.04 & 0.04 & 0.03 & 0.05 & 0.02 & 0.05 \\
\hline
\end{tabular}

Pre-print version. Visit http://digitalcommons.wayne.edu/humbiol/ after publication to acquire the final version. 


\begin{tabular}{|c|c|c|c|c|c|c|c|c|c|c|c|c|c|c|c|}
\hline \multirow[t]{5}{*}{ DXS7132 } & 13 & 0.26 & 0.34 & 0.18 & 0.45 & 0.25 & 0.21 & \multirow[t]{3}{*}{ Heterozygosity } & 13 & 0 & 0.01 & 0 & 0 & 0 & 0.01 \\
\hline & 14 & 0.27 & 0.22 & 0.5 & 0.16 & 0.29 & 0.44 & & 14 & 0.02 & 0 & 0 & 0 & 0.01 & 0 \\
\hline & 16 & 0.07 & 0.07 & 0 & 0.13 & 0.07 & 0.04 & & Exp & 0.67 & 0.63 & 0.54 & 0.57 & 0.63 & 0.67 \\
\hline & 17 & 0.08 & 0.04 & 0 & 0 & 0.05 & 0.03 & \multirow{4}{*}{ GATA172D05 } & 6 & 0.11 & 0.14 & 0.12 & 0.11 & 0.11 & 0.09 \\
\hline & 18 & 0.02 & 0 & 0 & 0 & 0.01 & 0.01 & & 7 & 0.01 & 0 & 0 & 0 & 0.01 & 0.01 \\
\hline \multirow[t]{2}{*}{ Heterozygosity } & Obs & 0.67 & 0.74 & 0.78 & 0.73 & 0.76 & 0.61 & & 8 & 0.16 & 0.21 & 0.16 & 0.21 & 0.11 & 0.19 \\
\hline & Exp & 0.83 & 0.79 & 0.74 & 0.73 & 0.79 & 0.72 & & 9 & 0.02 & 0.09 & 0 & 0.05 & 0.05 & 0.05 \\
\hline \multirow{9}{*}{ DXS9898 } & 8.3 & 0.2 & 0.15 & 0.15 & 0.11 & 0.15 & 0.04 & \multirow{6}{*}{ Heterozygosity } & 10 & 0.34 & 0.22 & 0.25 & 0.16 & 0.33 & 0.31 \\
\hline & 9 & 0.01 & 0.01 & 0 & 0 & 0 & 0 & & 11 & 0.2 & 0.21 & 0.25 & 0.26 & 0.34 & 0.27 \\
\hline & 10 & 0 & 0.01 & 0 & 0.03 & 0.01 & 0.01 & & 12 & 0.16 & 0.14 & 0.22 & 0.21 & 0.06 & 0.07 \\
\hline & 11 & 0.13 & 0.15 & 0.15 & 0.08 & 0.14 & 0.18 & & 14 & 0 & 0 & 0 & 0 & 0.01 & 0 \\
\hline & 12 & 0.31 & 0.33 & 0.47 & 0.39 & 0.34 & 0.2 & & Obs & 0.73 & 0.85 & 0.67 & 0.91 & 0.75 & 0.83 \\
\hline & 13 & 0.25 & 0.23 & 0.12 & 0.18 & 0.26 & 0.43 & & Exp & 0.8 & 0.82 & 0.81 & 0.84 & 0.74 & 0.79 \\
\hline & 14 & 0.1 & 0.06 & 0.09 & 0.21 & 0.11 & 0.09 & \multirow{3}{*}{ GATA31 E08 } & 9 & 0.16 & 0.19 & 0.23 & 0.08 & 0.16 & 0.14 \\
\hline & 15 & 0 & 0.04 & 0.03 & 0 & 0.01 & 0.03 & & 10 & 0.06 & 0.06 & 0 & 0.03 & 0.03 & 0.04 \\
\hline & 17 & 0 & 0 & 0 & 0 & 0 & 0.01 & & 11 & 0.19 & 0.23 & 0.3 & 0.17 & 0.22 & 0.31 \\
\hline \multirow[t]{2}{*}{ Heterozygosity } & Obs & 0.76 & 0.7 & 0.73 & 0.82 & 0.77 & 0.87 & \multirow{5}{*}{ Heterozygosity } & 12 & 0.27 & 0.31 & 0.17 & 0.36 & 0.25 & 0.34 \\
\hline & Exp & 0.76 & 0.78 & 0.78 & 0.76 & 0.78 & 0.78 & & 13 & 0.24 & 0.17 & 0.07 & 0.22 & 0.26 & 0.13 \\
\hline \multirow{4}{*}{ DXS6809 } & 28 & 0.02 & 0 & 0.03 & 0 & 0 & 0 & & 14 & 0.09 & 0.04 & 0.23 & 0.14 & 0.07 & 0.03 \\
\hline & 29 & 0.03 & 0.01 & 0.03 & 0 & 0.01 & 0.06 & & 15 & 0 & 0 & 0 & 0 & 0.01 & 0 \\
\hline & 31 & 0.11 & 0.15 & 0.09 & 0.16 & 0.09 & 0.07 & & Exp & 0.82 & 0.78 & 0.79 & 0.79 & 0.8 & 0.71 \\
\hline & 32 & 0.18 & 0.21 & 0.21 & 0.24 & 0.25 & 0.23 & & 11 & 0 & 0.03 & 0 & 0 & 0.01 & 0 \\
\hline
\end{tabular}

Pre-print version. Visit http://digitalcommons.wayne.edu/humbiol/ after publication to acquire the final version. 


\begin{tabular}{|c|c|c|ccc|cc|} 
& 33 & 0.3 & 0.22 & 0.44 & 0.24 & 0.28 & 0.24 \\
34 & 0.21 & 0.28 & 0.12 & 0.32 & 0.21 & 0.26 \\
35 & 0.09 & 0.09 & 0.03 & 0.03 & 0.08 & 0.06 \\
36 & 0.04 & 0.01 & 0.06 & 0.03 & 0.04 & 0.04 \\
& 37 & 0 & 0 & 0 & 0 & 0.01 & 0 \\
& 38 & 0 & 0 & 0 & 0 & 0 & 0 \\
Heterozygosity & Obs & 0.73 & 0.74 & 0.55 & 0.55 & 0.74 & 0.73 \\
& Exp & 0.81 & 0.82 & 0.77 & 0.75 & 0.8 & 0.81 \\
\hline Average het & Obs & $\mathbf{0 . 6 8}$ & $\mathbf{0 . 7 3}$ & $\mathbf{0 . 6 4}$ & $\mathbf{0 . 7 5}$ & $\mathbf{0 . 6 9}$ & $\mathbf{0 . 7 3}$ \\
\hline
\end{tabular}

\begin{tabular}{|c|c|c|ccc|c|c|} 
& 12 & 0 & 0 & 0.03 & 0 & 0 & 0 \\
DXS7423 & 13 & 0.03 & 0.04 & 0.23 & 0.03 & 0.04 & 0.03 \\
& 14 & 0.31 & 0.27 & 0.4 & 0.34 & 0.26 & 0.26 \\
& 15 & 0.48 & 0.53 & 0.2 & 0.55 & 0.46 & 0.47 \\
& 16 & 0.15 & 0.1 & 0.13 & 0.05 & 0.12 & 0.1 \\
& 17 & 0.03 & 0.04 & 0 & 0.03 & 0.11 & 0.14 \\
& Obs & 0.64 & 0.78 & 0.7 & 0.73 & 0.7 & 0.68 \\
& Exp & 0.67 & 0.66 & 0.72 & 0.54 & 0.71 & 0.65 \\
\hline \multirow{2}{*}{ Average het } & Exp & $\mathbf{0 . 7 4}$ & $\mathbf{0 . 7 4}$ & $\mathbf{0 . 7 3}$ & $\mathbf{0 . 7 1}$ & $\mathbf{0 . 7 3}$ & $\mathbf{0 . 7 3}$ \\
\hline
\end{tabular}

Cor $=$ Corrientes, Pos $=$ Posadas, EldA $=$ EldoradoA, EldB $=$ EldoradoB, $\mathbf{R e s}=$ Resistencia, $\mathbf{M N P}=$ Misión Nueva Pompeya. Osb $=$ observed, $\mathbf{E x p}=$ expected. 
Table 2. Proportion of Membership of Each Pre-defined Population in Each of the Two Clusters

\begin{tabular}{l|cc} 
Population & Cluster 1 & Cluster 2 \\
\hline Corrientes & 0.245 & 0.755 \\
Posadas & 0.256 & 0.744 \\
Eldorado A & 0.164 & 0.836 \\
Eldorado B & 0.336 & 0.664 \\
Resistencia & 0.299 & 0.701 \\
MNP & 0.390 & 0.610 \\
Mocoví & 0.645 & 0.355 \\
Wichí & 0.892 & 0.108 \\
Buenos Aires & 0.265 & 0.735 \\
Córdoba & 0.278 & 0.722 \\
Entre Ríos & 0.291 & 0.709 \\
Río Negro & 0.380 & 0.620 \\
Galicia & 0.103 & 0.897 \\
& &
\end{tabular}


Supplementary Table S1.

\begin{tabular}{|l|cc|cc|cc|cc|cc|cc|}
\hline \multirow{2}{*}{ Marcador } & \multicolumn{2}{|c|}{ Cor } & \multicolumn{2}{c|}{ Pos } & \multicolumn{2}{c|}{ EIdA } & \multicolumn{2}{c|}{ EldB } & \multicolumn{2}{c|}{ Res } & \multicolumn{2}{c|}{ MNP } \\
& $n_{\mathrm{a}}$ & $n_{e}$ & $n_{\mathrm{a}}$ & $n_{e}$ & $n_{\mathrm{a}}$ & $n_{e}$ & $n_{\mathrm{a}}$ & $n_{e}$ & $n_{\mathrm{a}}$ & $n_{e}$ & $n_{\mathrm{a}}$ & $n_{e}$ \\
\hline DXS8378 & 4 & 3.2 & 5 & 3 & 4 & 3.1 & 4 & 2.6 & 4 & 2.9 & 4 & 3 \\
DXS9902 & 5 & 3 & 5 & 3.2 & 5 & 3.6 & 5 & 3 & 7 & 3.1 & 6 & 3.8 \\
DXS7132 & 8 & 5 & 6 & 4.2 & 5 & 3 & 5 & 3.4 & 9 & 4.8 & 8 & 3.6 \\
DXS9898 & 6 & 4.4 & 8 & 4.7 & 6 & 3.5 & 6 & 4 & 7 & 4.3 & 8 & 3.7 \\
DXS6809 & 9 & 5.3 & 8 & 4.9 & 8 & 3.8 & 6 & 4.1 & 9 & 4.9 & 8 & 5.4 \\
DXS6789 & 10 & 3.4 & 9 & 3.5 & 5 & 2.7 & 7 & 4 & 9 & 3.5 & 8 & 3 \\
DXS7133 & 7 & 3 & 6 & 2.9 & 4 & 2.2 & 4 & 2.3 & 7 & 2.6 & 5 & 2.6 \\
GATA172D05 & 7 & 4.6 & 6 & 5.4 & 5 & 4.7 & 6 & 5.1 & 8 & 3.9 & 7 & 4.5 \\
GATA31 E08 & 6 & 4.9 & 6 & 4.6 & 5 & 4.4 & 6 & 4.3 & 7 & 4.7 & 6 & 4 \\
DXS7423 & 5 & 2.9 & 6 & 2.7 & 5 & 3.7 & 5 & 2.4 & 6 & 3.3 & 5 & 3.2 \\
\hline$n_{\mathbf{x}}$ & 6,7 & & 6,5 & 5,2 & 5,4 & 7,3 & & 6,5 \\
\hline
\end{tabular}

Number of alleles observed $\left(n_{\mathrm{a}}\right)$, number of effective alleles $\left(n_{\mathrm{e}}\right)$ and Average number $\left(n_{\mathrm{x}}\right)$ for

Cor $=$ Corrientes, $\mathbf{P o s}=$ Posadas, $\mathbf{E l d A}=$ EldoradoA, $\mathbf{E l d B}=$ EldoradoB, $\mathbf{R e s}=$ Resistencia

MNP= Misión Nueva Pompeya. 
Supplementary Table 2.

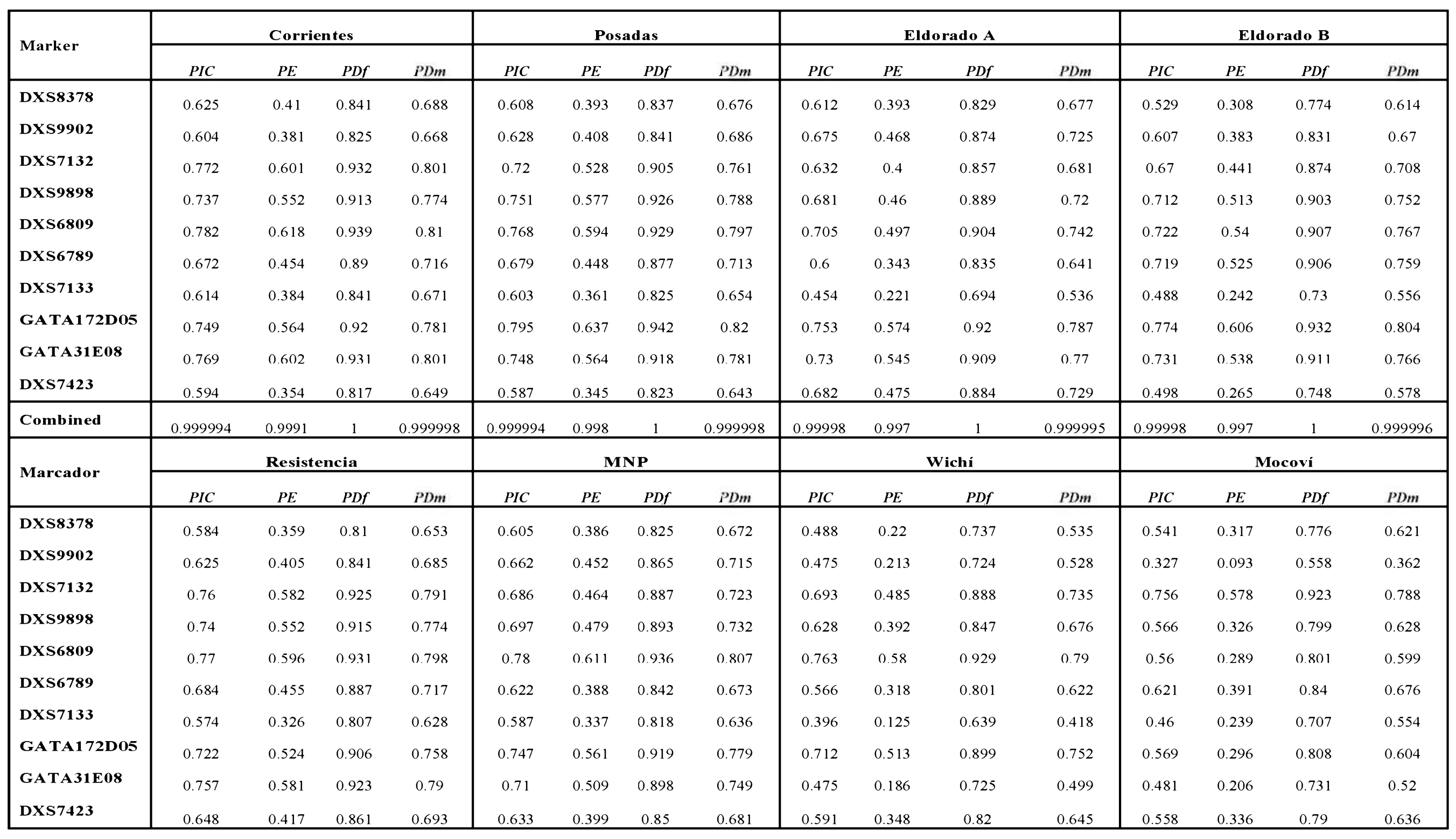

Pre-print version. Visit http://digitalcommons.wayne.edu/humbiol/ after publication to acquire the final version. 
$P I C=$ polymorphic information content, $P E=$ power of exclusion, $P D f=$ power of discrimination females and $P D m=$ power of discrimination males for Corrientes, Posadas, Eldorado A, Eldorado B, Resistencia, Misión Nueva Pompeya, Wichí and Mocoví. MNP

Misión Nueva Pompeya. Markers with PIC values greater than 0.5 are considered very informative, with values between 0.25 and 0.50 , informative and with values less than 0.25 , not very informative. 
Supplementary Table S3.

\begin{tabular}{|c|c|c|c|c|c|c|c|c|c|c|c|c|c|}
\hline $\begin{array}{ll} & R_{\mathrm{st}} \\
F_{\mathrm{st}} & \end{array}$ & Cor & Pos & Eld A & Eld B & Res & MNP & Mocoví & Wichí & $\mathbf{B A}$ & Cba & $\mathbf{E R}$ & $\mathbf{R N}$ & Galicia \\
\hline Cor & - & -0.002 & -0.012 & 0.004 & 0.001 & $0.050 *$ & $0.046^{*}$ & $0.126 \dagger$ & -0.003 & -0.005 & -0.005 & -0.007 & 0.001 \\
\hline Pos & -0.002 & - & -0.019 & -0.01 & -0.006 & $0.022 *$ & 0.027 & $0.105 \dagger$ & -0.003 & -0.003 & 0.019 & -0.005 & 0.009 \\
\hline EId A & 0.002 & $0.010^{*}$ & - & -0.02 & -0.013 & $0.033^{*}$ & 0.038 & $0.142 \digamma$ & -0.01 & -0.012 & 0.004 & -0.01 & 0 \\
\hline EldB & 0.008 & 0 & $0.019^{*}$ & - & -0.009 & 0.007 & 0.005 & $0.090 *$ & 0.002 & 0.002 & 0.035 & 0.003 & 0.016 \\
\hline Res & 0 & 0 & 0.007 & $0.012 \nrightarrow$ & $0 . \overline{003}$ & $0.023^{*}$ & 0.022 & $0.078 \dagger$ & 0.001 & 0 & 0.023 & -0.002 & $0.014 \dagger$ \\
\hline MNP & 0.005 & 0.003 & $0.014^{*}$ & $0.016^{*}$ & $0.045 \dagger$ & - & 0.001 & $0.033^{*}$ & $0.036 \digamma$ & $0.039 *$ & $0.121 \dagger$ & $0.049 \digamma$ & $0.064 \dagger$ \\
\hline Mocoví & $0.059 \uparrow$ & $0.049 \dagger$ & $0.070 \dagger$ & $0.064 \dagger$ & $0.056 \dagger$ & $0.045 \dagger$ & - & $0.048 \uparrow$ & $0.037^{*}$ & 0.037 & $0.102 \uparrow$ & $0.044^{*}$ & $0.062 *$ \\
\hline Wichí & $0.065 \digamma$ & $0.054\rceil$ & $0.076+$ & $0.056 t$ & 0 & $0.055 t$ & 0.055 & - & $0.083 \nrightarrow$ & $0.099 \dagger$ & $0.252 \dagger$ & $0.150 \dagger$ & $0.128 \dagger$ \\
\hline $\mathbf{B A}$ & -0.001 & -0.001 & 0.001 & $0.010 *$ & 0 & $0.006 t$ & $0.047 \dagger$ & $0.053 \nrightarrow$ & - & -0.003 & 0.007 & -0.004 & 0.004 \\
\hline Cba & $0.004 *$ & $0.003 *$ & -0.003 & $0.014 \dagger$ & $0.009 *$ & 0.004 & $0.042 †$ & $0.057 \nrightarrow$ & $0.002 *$ & $0 . \overline{003}$ & 0.002 & -0.007 & 0.004 \\
\hline ER & $0.007 *$ & $0.009 *$ & -0.018 & $0.019 *$ & 0.003 & 0.009 & $0.057 \nrightarrow$ & $0.057 \dagger$ & 0.004 & -0.001 & 0.003 & 0.002 & -0.003 \\
\hline $\mathbf{R N}$ & 0.002 & 0.002 & 0.001 & $0.013 \dagger$ & $0.008 \dagger$ & 0.002 & $0.033 \dagger$ & $0.046 \dagger$ & 0.003 & $0.006 \uparrow$ & $0.007 *$ & - & 0.001 \\
\hline Galicia & 0.003 & $0.005 *$ & -0.001 & $0.017 \dagger$ & & $0.014 \dagger$ & $0.057 \dagger$ & $0.074 \dagger$ & $0.004 \uparrow$ & & & $0.007 *$ & - \\
\hline
\end{tabular}

Below diagonal $F_{\text {st }}$ distances and above diagonal $R_{\text {st }}$ distances. Values marked with * (highlighted in bold) correspond to $p$-values $<$

0.05 while values marked with correspond to $p$-values $<0.005 . \mathbf{C o r}=$ Corrientes, Pos $=$ Posadas, EldA $=$ EldoradoA, Eld $\mathbf{B}=$

EldoradoB, $\mathbf{R e s}=$ Resistencia, $\mathbf{M N P}=$ Misión Nueva Pompeya, $\mathbf{B A}=$ Buenos Aires, $\mathbf{C b a}=\mathrm{Có}$ doba, $\mathbf{E R}=$ Entre Ríos, $\mathbf{R N}=$ Río Negro. 


\section{Figure Captions}

Figure 1. Geographical location of the populations analysed and other populations used for comparisons. Chaco, Corrientes, Misiones (this work); Entre Ríos, Córdoba, Buenos Aires and Río Negro (Gusmão et al. 2009); Mocoví and Wichí indigenous from Gran Chaco region (Glesmann et al. 2013).

Figure 2. MDS graphc using $R_{\mathrm{st}} \mathbf{C o r}=$ Corrientes, $\mathbf{P o s}=$ Posadas, $\mathbf{E l d A}=$ EldoradoA, $\mathbf{E l d B}=$ EldoradoB, Res $=$ Resistencia, $\mathbf{M N P}=$ Misión Nueva Pompeya, $\mathbf{M o c}=$ Mocoví, $\mathbf{W i c h}=$ Whichí, $\mathbf{B A}=$ Buenos Aires, $\mathbf{C b a}=$ Córdoba, $\mathbf{E R}=$ Entre Ríos, $\mathbf{R N}=$ Río Negro, $\mathbf{G a l}=$ Galicia.

Figure 3. Bar plot $k=2$ for Corrientes (1), Posadas (2), Eldorado A (3), Eldorado B (4), Resistencia (5), Misión Nueva Pompeya (6), Mocoví (7), Wichí (8), Buenos Aires (9), Córdoba (10), Entre Ríos (11), Rio Negro (12), Galicia (13). 
Figure 1.

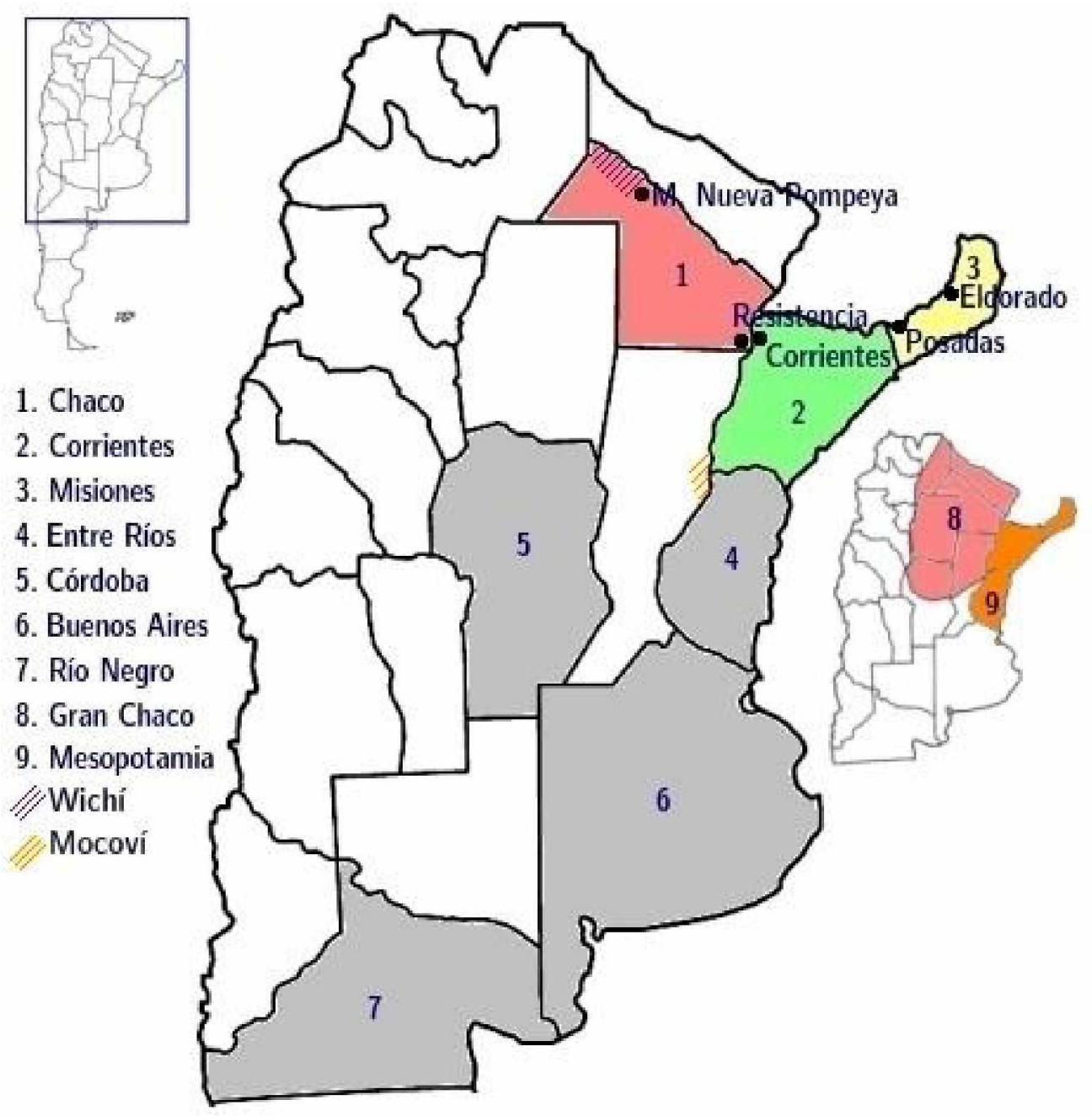


Figure 2.

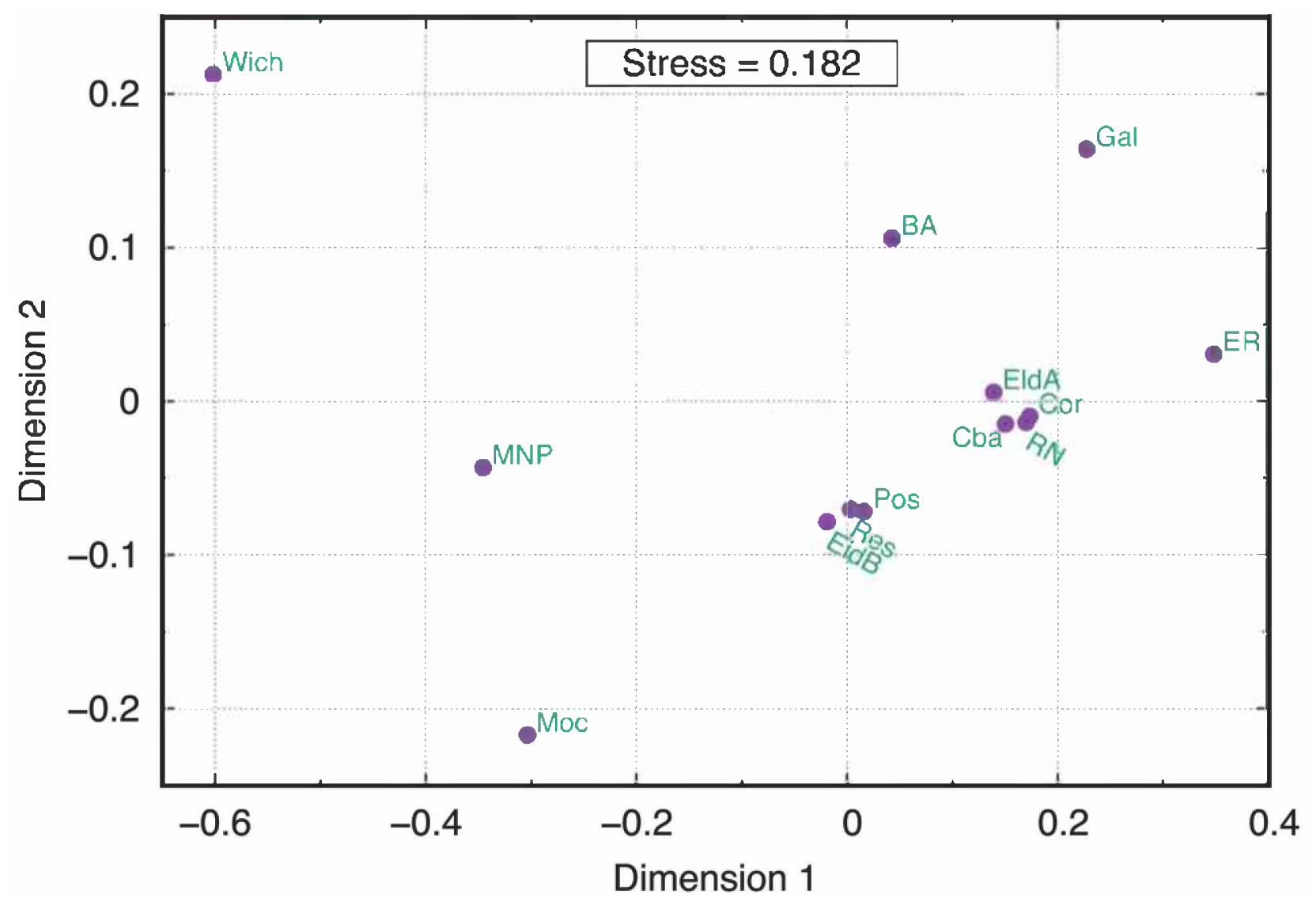

Pre-print version. Visit http://digitalcommons.wayne.edu/humbiol/after publication to acquire the final version. 
Figure 3.

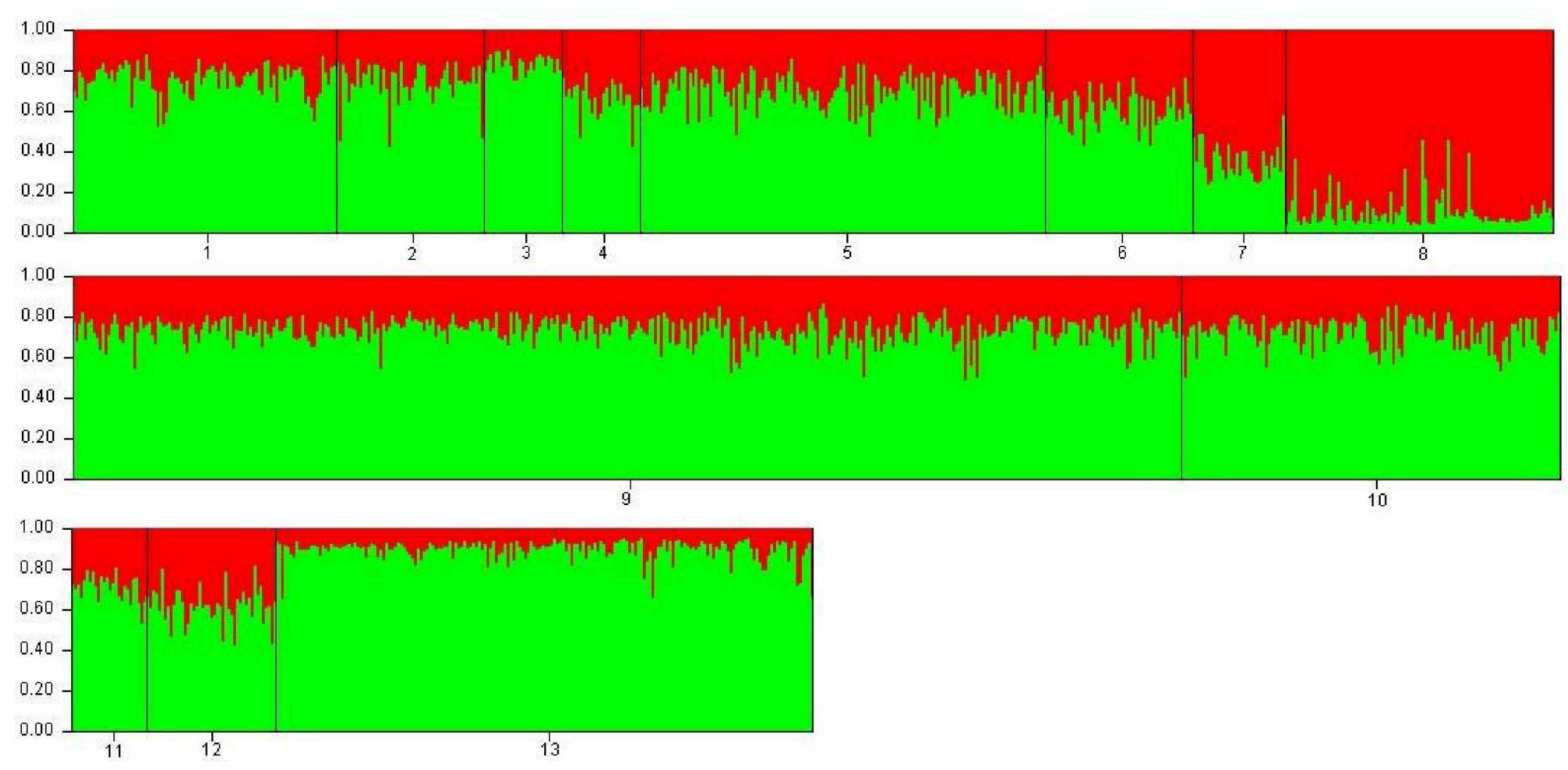

